\author{
Asian Economic and Financial Review \\ $\operatorname{ISSN}(e): \quad 2222-6737$ \\ $\operatorname{ISSN}(p): \quad 2305-2147$ \\ DOI: 10.18488/journal.aefr.2021.119.693.709 \\ Vol. 11, No. 9, 693-709. \\ (C) 2021 AESS Publications. All Rights Reserved. \\ URL: www.aessweb.com \\ check for
updates
}

\title{
THE IMPACT OF FIRM CHARACTERISTICS ON FIRM PERFORMANCE DURING THE COVID-19 PANDEMIC: EVIDENCE FROM SAUDI ARABIA
}

Helmi A.

Boshnak $^{1+}$

Abdullatif M.

Basheikh $^{2}$

Mazen S. Basaif
${ }^{1,2, s}$ Faculty of Economics and Administration, King Abdulaziz University, Saudi Arabia.

:Email:boboshnak1@kau.edu.sa

sEmail:bashiekh@kau.edu.sa

'Email:msasbasaif@kau.edu.sa

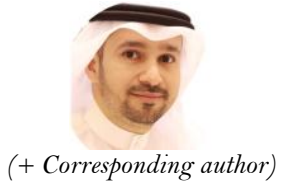

(+ Corresponding author)

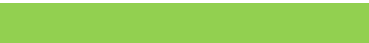

Article History

Received: 31 May 2021 Revised: 5 July 2021 Accepted: 3 August 2021 Published: 23 August 2021

\section{Keywords}

Firm characteristics COVID-19 pandemic Operational performance Financial performance Market performance

Saudi Arabia.

JEL Classification: D22, G0, G3, G14, L25.

\begin{abstract}
This study aims to examine the impact of firm characteristics on the operational, financial, and market performance of Saudi listed firms during the COVID-19 pandemic. This study applies a number of regression models over the period from Q3 2019 to Q3 2020, thereby enabling the examination of key drivers in the pre- and postcrisis periods. We find that the operational, financial, and market performance measures all saw a significant drop with the onset of the COVID-19 pandemic. The models show that larger firms displayed better performance both before and after the pandemic, though there is some evidence of a weakening of this relation for return on equity (ROE) with the onset of the pandemic. Leverage is a clear negative driver of firm performance across the three measures both before and after the onset of the pandemic, though there is evidence that the effect strengthens after the crisis. Neither sales revenue scale nor firm liquidity exerts a significant impact on firm performance measures. Certain industry types, such as materials (petrochemicals), consumer services, real estate, and consumer durables \& apparel appear most affected by the pandemic. Surprisingly, the regression models do not show a significant impact on the scale of the performance measures with the onset of the pandemic. The results of this study have wide implications for decision-makers, illustrating the imperative for regulatory bodies, governments and central banks to combine forces to reduce the financial and economic impacts of the pandemic both now and in the future.
\end{abstract}

Contribution/Originality: This study contributes to the existing literature by examining the relationship between firm characteristics and firm performance of listed firms which are included in all business sectors in Saudi Stock Exchange. This is the first study to apply the pre-post comparison method to explain the impact of COVID19 pandemic on firm performance by employing three different performance indicators.

\section{INTRODUCTION}

The spread of the novel coronavirus (COVID-19) has significantly impacted the global economy and, in particular, the health care, transportation, and retail industries, among others. However, there remains great uncertainty regarding the extent of that impact as disease transmission and mortality are difficult to predict, as is the efficacy of government policy and business strategy responses. More than 100 countries have announced either 
partial or full lockdowns to avoid the worst effects of the pandemic. In common with many countries, the government of Saudi Arabia has responded by imposing lockdowns (restricting the movement of people), travel bans (closing international borders), along with a raft of fiscal stimulus packages to provide support to businesses losing output and workers losing jobs.

The Saudi Vision 2030 Dynamic Input-Output Table (IOT) scenario study reveals that the pandemic lockdown has resulted in a $7.0 \%$ reduction in real GDP compared to the baseline level. The study predicts that the hit to GDP is partly offset by the government's fiscal countermeasures, boosting real GDP by $2.6 \%$ (Havrlant, Darandary, \& Muhsen, 2020).

The COVID-19 outbreak may affect firms' accounting performance (Fu \& Shen, 2020), their stock market performance (Iyke, 2020; Liu, Wang, \& Lee, 2020; Narayan, 2020), and other aspects of business operations (Hagerty \& Williams, 2020). The spread of the pandemic has caused a sudden and significant drop in revenue for firms across many industries. It is therefore useful to evaluate the impact of the pandemic on Saudi corporate performance. Recent studies underline the distinctive nature of the global crisis caused by the pandemic compared to previous crises in terms of its origin, complexity, and magnitude (Ding, Levine, Lin, \& Xie, 2020; Ramelli \& Wagner, 2020). In this study, we examine the impact of firm characteristics during the pandemic on the performance of Saudi listed firms. We employ three different performance indicators: firm operational performance (return on assets (ROA)), firm financial performance (return on equity (ROE)), and firm market performance (earnings per share (EPS)). To our best knowledge, this is the first study to examine the impact of the COVID-19 pandemic on Saudi firm performance. We thus examine whether the dynamics of firm performance generation, in addition to the drop in performance, are affected by the pandemic.

\section{LITERATURE REVIEW AND HYPOTHESES DEVELOPMENT}

There are significant global consequences of the COVID-19 pandemic for both human life and the economy. As many consumers are confined to their homes due to national and regional lockdowns, economic activity has been significantly curtailed, and thus many of the world's popular brands could disappear entirely as selected corporations fail (Tucker, 2020). Bagnera \& Steinberg (2020) observe that almost 90\% of airline personnel have been laid off, hotels are running at $20 \%$ of their usual capacity, and the tourism and travel industry is set to suffer significant financial losses in 2020. In many countries, sporting events, music concerts, cultural events, and other activities which involved large gatherings have been suspended indefinitely.

Government enforced lockdowns around the world to attempt to counter the spread of the pandemic have resulted in pervasive slumps in economic growth. Many firms in the manufacturing industry were initially shut down, giving rise to major disruption in production processes and supply chains. However, the main concerns relate to the well-being of employees, the efficacy of disaster preparation, and the ability of businesses to deal with the challenging circumstances. Global restrictions imposed on travel led to a slowdown in mobility and business production, in turn, leading to a significant fall in global demand for oil, and falling oil prices. In Saudi Arabia, a key oil producing country, this has led to significant effects for the petrochemical and consumer services sectors. In addition, the Saudi Ministry of Finance recently directed all government agencies not to renew contracts for real estate rental unless renters accepted a $20 \%$ rent reduction, thereby placing the real estate sector under further pressure. The COVID-19 pandemic has given rise to major health disasters across the globe. Since January 2020, over 90 million people globally have become infected with the virus, with almost no country or region spared (Coronavirus Update, 2021). The highly contagious nature of the virus has forced most countries to adopt social distancing measures along with quarantine enforcement and the closure of public spaces. The effect of this has dramatically reduced the demand for many goods and services, leading to a decline in exports and imports, and significant hits to global GDP. In the context of Saudi Arabia, this resulted in a sharp fall in GDP of around 7\% in the first quarter of 2020 (Havrlant et al., 2020). 
There is a paucity of research on the impact on corporate performance. For example, Shen, Fu, Pan, Yu, \& Chen (2020) examined the impact of the pandemic on Chinese corporate performance and found evidence of a significant negative effect. Rababah, Al-Haddad, Sial, Chunmei, \& Cherian (2020) found that small- and mediumsized Chinese firms are most affected by the pandemic, and that selected industries suffered a sharper drop in financial performance compared to other industries. This study aims to examine the impact of firm characteristics during the COVID-19 pandemic on the operational, financial, and market performance of Saudi listed firms. We propose the following hypotheses:

H1: Firm size is positively associated with the operational, financial, and market performance of Saudi listed firms during the COVID-19 pandemic.

H2: Firm revenue is negatively associated with the impact on the operational, financial, and market performance of Saudi listed firms during the COVID-19 pandemic.

H3: Firm liquidity is negatively associated with the operational, financial, and market performance of Saudi listed firms during the COVID-19 pandemic.

H4: Firm leverage is negatively associated with the operational, financial, and market performance of Saudi listed firms during the COVID-19 pandemic.

H5: Industry type is negatively associated with the operational, financial, and market performance of Saudi listed firms during the COVID-19 pandemic.

\section{RESEARCH METHODOLOGY}

To examine the impact of firm characteristics during the pandemic on firm performance of Saudi listed firms, descriptive and multivariate regression analyses are applied to test the relationship between firm characteristic drivers of firm performance before and after the pandemic, as well as throughout the period, consistent with the approach in the extant literature (Rababah et al., 2020; Shen et al., 2020; Song, Yeon, \& Lee, 2021).

\subsection{Data Sample}

The sample consists of 126 non-financial Saudi (Tadawul) listed firms selected by market sector over the four quarters spanning from Q3 2019 to Q3 2020, giving 504 quarterly reports from firms across the sectors, and constituting $62 \%$ of the total population of firms. The sample consists of Saudi joint stock firms with shares traded on the Tadawul during the study period, and with fiscal year ends of December $31^{\text {st }}$. Firms with different fiscal year ends or with financial data unavailable during the study period are excluded. Additionally, certain sectors, such as banks, insurance, and real estate investment traded funds (REITs) are excluded as their financial statements are different from those of other sectors given that they are presented in accordance with Saudi Central Bank standards rather than the Saudi Organization for Certified Public Accountants standards and IFRS. The sample selection process is detailed in Table 1 and the Tadawul's industry classification is given in Table 2.

Table-1. The study sample selection process.

\begin{tabular}{l|c}
\hline \multicolumn{2}{c}{ Table-1. The study sample selection process. } \\
\hline Initial Sample & Q3 2019 to Q3 2020 \\
\hline Less: & -12 \\
\hline Banking firms & -31 \\
\hline Insurance firms & -17 \\
\hline REITs & -16 \\
\hline Other firms & 126 \\
\hline Final sample & 126 \\
\hline Selected firms & $62 \%$ \\
\hline Percentage of selected firms to total market population & \\
\hline Source: Tadawul $(2021)$. &
\end{tabular}


Table-2. Tadawul market sector classification.

\begin{tabular}{c|l}
\hline Sector No. & Sector Description \\
\hline 1 & Energy \\
\hline 2.1 & Materials (petrochemicals) \\
\hline 2.2 & Materials (others) \\
\hline 3 & Capital Goods \\
\hline 4 & Commercial \& Professional Services \\
\hline 5 & Transportation \\
\hline 6 & Consumer Durables \& Apparel \\
\hline 7 & Consumer Services \\
\hline 8 & Media \& Entertainment \\
\hline 9 & Retailing \\
\hline 10 & Food \& Staples Retailing \\
\hline 11 & Food \& Beverages \\
\hline 13 & Health Care Equipment \& Services \\
\hline 14 & Pharma, Biotech \& Life Science \\
\hline 15 & Diversified Financials \\
\hline 16 & Software \& Services \\
\hline 17 & Telecommunication Services \\
\hline 18 & Real Estate Management \& Development \\
\hline Source: Tadawul (2021).
\end{tabular}

\subsection{Variable Measurement}

This paper examines the effect of firm characteristics during the COVID-19 pandemic on three commonly employed measures of firm performance: operational performance using return on assets (ROA); financial performance using return on equity (ROE); and market performance using firm earnings per share (EPS). The independent variables employed in the study models include the following firm characteristics: firm size (SIZE), revenue $(R E V)$, liquidity $(L I Q)$, leverage $(L E V)$, and industry type $(I N D)$. The study variable labels and definitions are given in Table 3 .

Table-3. Definitions and measurements of the study variables

\begin{tabular}{l|l|l}
\hline Variable & Label & Measurement \\
\hline $\begin{array}{l}\text { Dependent variable: } \\
\text { Operational performance }\end{array}$ & ROA & Ratio of total net income to total assets for firm i. \\
\hline Financial performance & ROE & $\begin{array}{l}\text { Ratio of total net income to total shareholders' equity for firm i. } \\
\text { Earnings per share for each period for firm i. }\end{array}$ \\
\hline Market performance & EPS & The logarithm of total assets for firm i. \\
\hline Independent variables: & SIZE & Firms' revenue (Saudi Riyals)/1,ooo. \\
\hline Firm size & REV & Current assets divided by current liabilities for firm i. \\
\hline Revenue & LIQ & Total liabilities divided by total assets for firm i. \\
\hline Liquidity & LEV & $\begin{array}{l}\text { Dummy variable that equals one if firm i belongs to a given } \\
\text { industrial sector, and zero otherwise. }\end{array}$ \\
\hline Leverage & IND & $\begin{array}{l}\text { Dummy variable that equals one in the presence of the COVID-19 } \\
\text { pandemic, and zero otherwise. }\end{array}$ \\
\hline Industry type & COVID
\end{tabular}

\subsection{The Study Models}

To examine the impact of firm characteristics on firm performance during the COVID-19 pandemic, three multiple regression models are estimated. Models I to III, respectively, test the impact of firm characteristics on operational performance (ROA), financial performance (ROE), and market performance (EPS). Each model splits the sample into before and after the onset of the pandemic. Models IV to VI have the same model specifications but include a dummy for the onset of the pandemic and thus span the whole four quarters. They test whether the pandemic has impacted the level of ROA, ROE, and EPS. 
Model I examines the relation between operational performance (ROA) and firm characteristics.

$$
\mathrm{ROA}_{\mathrm{it}}=\beta_{0}+\beta_{1} \mathrm{SIZE}_{\mathrm{it}}+\beta_{2} \mathrm{REV}_{\mathrm{it}}+\beta_{\mathrm{a}} \mathrm{LIQ}_{\mathrm{it}}+\beta_{4} \mathrm{LEV} \mathrm{it}_{\mathrm{it}}+\beta_{5} \mathrm{IND}_{\mathrm{it}}+\varepsilon_{\mathrm{it}}
$$

Model II examines the relation between financial performance (ROE) and firm characteristics.

$$
\mathrm{ROE}_{i \mathrm{t}}=\beta_{0}+\beta_{1} \mathrm{SIZE}_{\text {it }}+\beta_{2} \mathrm{REV}_{\mathrm{it}}+\beta_{\mathrm{g}} \mathrm{LIQ}_{\mathrm{it}}+\beta_{4} \mathrm{LEV}_{\mathrm{it}}+\beta_{5} \mathrm{IND}_{\text {it }}+\varepsilon_{\mathrm{it}}
$$

Model III examines the relation between market performance (EPS) and firm characteristics.

$$
\mathrm{EPS}_{i t}=\beta_{0}+\beta_{1} \mathrm{SIZE}_{i t}+\beta_{2} \mathrm{REV}_{\mathrm{it}}+\beta_{\mathrm{a}} \mathrm{LIQ}_{\mathrm{it}}+\beta_{4} \mathrm{LEV}_{\mathrm{it}}+\beta_{5} \mathrm{IND}_{\mathrm{it}}+\varepsilon_{\mathrm{it}}
$$

Model IV examines the relation between operational performance (ROA) and firm characteristics + COVID-19 pandemic dummy.

$$
\mathrm{ROA}_{\mathrm{it}}=\beta_{0}+\beta_{1} \mathrm{SIZE}_{\mathrm{it}}+\beta_{2} \mathrm{REV}_{\mathrm{it}}+\beta_{\mathrm{a}} \mathrm{LIQ}_{\mathrm{it}}+\beta_{4} \mathrm{LEV}_{\mathrm{it}}+\beta_{5} \mathrm{IND}_{\mathrm{it}}+\beta_{6} \mathrm{COVID}_{\mathrm{t}}+\varepsilon_{\mathrm{it}}
$$

Model V examines the relation between financial performance (ROE) and firm characteristics + COVID-19 pandemic dummy.

$$
\mathrm{ROE}_{i t}=\beta_{0}+\beta_{1} \mathrm{SIZE}_{\mathrm{it}}+\beta_{2} \mathrm{REV}_{\mathrm{it}}+\beta_{\mathrm{a}} \mathrm{LIQ}_{\mathrm{it}}+\beta_{4} \mathrm{LEV}_{\mathrm{it}}+\beta_{5} \mathrm{IND}_{\text {it }}+\beta_{6} \mathrm{COVID}_{\mathrm{t}}+\varepsilon_{\mathrm{it}}
$$

Model VI examines the relation between market performance (EPS) and firm characteristics + COVID-19 pandemic dummy.

$$
\mathrm{EPS}_{\text {it }}=\beta_{0}+\beta_{1} \mathrm{SIZE}_{i \mathrm{t}}+\beta_{2} \mathrm{REV}_{\mathrm{it}}+\beta_{\mathrm{a}} \mathrm{LIQ}_{\mathrm{it}}+\beta_{4} \mathrm{LEV}_{\mathrm{it}}+\beta_{5} \mathrm{IND}_{\mathrm{it}}+\beta_{6} \mathrm{COVID}_{\mathrm{t}}+\varepsilon_{\mathrm{it}}
$$

Where: $\mathrm{i}=$ company identifier and $\mathrm{t}=$ year identifier; $\mathrm{ROA}=$ operational performance proxy; $\mathrm{ROE}=$ financial performance proxy; EPS = market performance proxy; SIZE = firm size; REV = firm revenue; LIQ = firm liquidity; LEV = firm leverage; IND = industry type; COVID = COVID-19 pandemic dummy; $\varepsilon=$ error term.

\section{RESULTS AND DISCUSSION}

\subsection{Descriptive Statistics Analysis}

Table 4 provides the descriptive statistics for the model variables before and after the onset of the COVID-19 pandemic, along with the differences in variables in response to the pandemic. Mean operational performance $(R O A)$ before and after the onset of the pandemic were $6 \%$ and $4 \%$, respectively, with ranges of $-11.6 \%$ to $12 \%$ and $-21 \%$ to $11 \%$, respectively, thereby the mean operational performance $(R O A)$ decreased by $33 \%$ following the onset of the pandemic. Mean financial performance $(R O E)$ before the pandemic was $5 \%$ with a range of $-56 \%$ to $18 \%$ and was $1 \%$ with the onset of the pandemic with a range of $-63 \%$ to $15 \%$, thereby dropping by $120 \%$ with the onset of the pandemic. Mean market performance $(E P S)$ before and after the pandemic was around 0.30 and 0.10 Riyal, respectively, and ranged from -22 to 8 Riyal and -63 to 9 Riyal, respectively, and thus it decreased markedly by $67 \%$. 
Asian Economic and Financial Review, 2021, 11(9): 693-709

Table-4. Descriptive statistics for the model variables before and after the onset of the Covid-19 pandemic

\begin{tabular}{|c|c|c|c|c|c|c|c|c|c|c|c|c|}
\hline & \multicolumn{4}{|c|}{ Before COVID-19 } & \multicolumn{4}{|c|}{ After COVID-19 } & \multicolumn{4}{|c|}{ Difference ratio } \\
\hline & Minimum & Maximum & Mean & $\begin{array}{c}\text { Std. } \\
\text { Deviation }\end{array}$ & Minimum & Maximum & Mean & $\begin{array}{c}\text { Std. } \\
\text { Deviation }\end{array}$ & Minimum & Maximum & Mean & $\begin{array}{c}\text { Std. } \\
\text { Deviation }\end{array}$ \\
\hline Operational performance (ROA) & -0.116 & 0.124 & 0.006 & 0.023 & -0.212 & 0.112 & 0.004 & 0.027 & $83 \%$ & $-10 \%$ & $-33 \%$ & $17 \%$ \\
\hline Financial performance (ROE) & -0.556 & 0.183 & 0.005 & 0.065 & -0.629 & 0.151 & -0.001 & 0.075 & $13 \%$ & $-17 \%$ & $-120 \%$ & $15 \%$ \\
\hline Market performance (EPS) & -21.750 & 8.320 & 0.298 & 2.950 & -62.690 & 8.680 & 0.099 & 6.045 & $188 \%$ & $4 \%$ & $-67 \%$ & $105 \%$ \\
\hline Firm size Log-TA & 4.799 & 8.685 & 6.377 & 0.697 & 4.638 & 8.702 & 6.380 & 0.694 & $-3 \%$ & $0 \%$ & $\mathrm{O} \%$ & $\mathrm{O} \%$ \\
\hline Revenue & $\mathrm{O}$ & 33689.500 & 1039.207 & 3520.227 & -311 & 29295.071 & 974.444 & 3258.266 & - & $-13 \%$ & $-6 \%$ & $-7 \%$ \\
\hline Liquidity & 0.007 & 13.456 & 1.593 & 1.805 & 0.002 & 16.716 & 1.603 & 1.939 & $-71 \%$ & $24 \%$ & $1 \%$ & $7 \%$ \\
\hline Energy & $\mathrm{O}$ & 1 & 0.03 & 0.176 & $\mathrm{O}$ & 1 & 0.03 & 0.176 & - & $0 \%$ & $0 \%$ & $0 \%$ \\
\hline
\end{tabular}

Table-5. Spearman correlation analysis before the Covid-19 pandemic

\begin{tabular}{|c|c|c|c|c|c|c|c|c|c|c|c|c|c|c|c|c|c|c|c|c|c|c|c|c|c|c|c|}
\hline & & \multirow{2}{*}{ ROA } & \multirow{2}{*}{ ROE } & \multirow{2}{*}{ EPS } & \multirow{2}{*}{ SIZE } & \multirow{2}{*}{ REV } & \multirow{2}{*}{ LIQ } & \multirow{2}{*}{ LEV } & \multicolumn{19}{|c|}{ Tadawul's Market Sectors - Industry Type } \\
\hline & & & & & & & & & 1 & 2.1 & 2.2 & 3 & 4 & 5 & 6 & 7 & 8 & \begin{tabular}{|l}
9 \\
\end{tabular} & 10 & 11 & 12 & 13 & 14 & 15 & 16 & 17 & 18 \\
\hline \multicolumn{2}{|c|}{ SIZE } & $0.127^{*}$ & 0.111 & $0.256^{* * *}$ & 1 & & & & & & & & & & & & & & & & & & & & & & \\
\hline \multicolumn{2}{|c|}{ REV } & 0.023 & 0.047 & $0.186^{* * *}$ & $0.577^{*} * *$ & 1 & & & & & & & & & & & & & & & & & & & & & \\
\hline \multicolumn{2}{|c|}{$\mathrm{LIQ}$} & $0.156^{*}$ & 0.106 & 0.091 & $-0.157^{*}$ & -0.036 & 1 & & & & & & & & & & & & & & & & & & & & \\
\hline \multicolumn{2}{|c|}{ LEV } & $-.171 * * *$ & $-0.205 * *$ & $-0.225 * *$ & $0.332 * *$ & $0.163^{* * *}$ & $-0.545 * *$ & 1 & & & & & & & & & & & & & & & & & & & \\
\hline \multirow{19}{*}{ 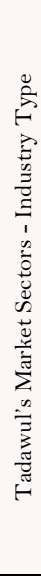 } & 1 & -0.033 & -0.039 & 0.045 & 0.119 & 0.071 & 0.004 & 0.080 & 1 & & & & & & & & & & & & & & & & & & \\
\hline & 2.1 & -0.090 & -0.032 & 0.122 & $0.320^{* * *}$ & $0.234 * * *$ & 0.008 & -0.023 & -0.059 & 1 & & & & & & & & & & & & & & & & & \\
\hline & 2.2 & 0.106 & 0.026 & -0.032 & -0.119 & -0.111 & 0.049 & $-0.189^{* *}$ & -0.099 & $-.177^{* *}$ & 1 & & & & & & & & & & & & & & & & \\
\hline & 3 & -0.072 & $-0.194 * * *$ & $-0.225 * *$ & $-0.156^{*}$ & -0.072 & 0.033 & 0.085 & -0.056 & -0.100 & $-0.169^{* *}$ & 1 & & & & & & & & & & & & & & & \\
\hline & 4 & $0.151^{*}$ & $0.133^{*}$ & $0.171 * *$ & -0.027 & -0.029 & -0.027 & 0.073 & -0.028 & -0.051 & -0.085 & -0.048 & 1 & & & & & & & & & & & & & & \\
\hline & 5 & 0.039 & 0.035 & 0.062 & -0.015 & -0.042 & 0.011 & -0.029 & -0.037 & -0.066 & -0.111 & -0.063 & -0.032 & 1 & & & & & & & & & & & & & \\
\hline & 6 & -0.089 & -0.060 & $-0.187^{* * *}$ & $-0.155^{*}$ & -0.057 & $0.133^{*}$ & -0.070 & -0.040 & -0.073 & -0.122 & -0.069 & -0.035 & -0.045 & 1 & & & & & & & & & & & & \\
\hline & 7 & 0.047 & 0.056 & 0.040 & $\begin{array}{l}-0.072 \\
\end{array}$ & -0.061 & -0.023 & 0.038 & -0.047 & -0.084 & $-0.142^{*}$ & -0.081 & -0.041 & -0.053 & -0.058 & 1 & & & & & & & & & & & \\
\hline & 8 & 0.022 & 0.066 & 0.055 & 0.049 & -0.011 & -0.010 & 0.121 & $\begin{array}{l}-0.016 \\
\end{array}$ & -0.029 & -0.049 & -0.028 & -0.014 & -0.018 & -0.020 & -0.023 & 1 & & & & & & & & & & \\
\hline & 9 & $0.130^{*}$ & $0.145^{*}$ & $0.154 *$ & -0.054 & -0.016 & -0.093 & $0.131^{*}$ & -0.040 & -0.073 & -0.122 & -0.069 & -0.035 & -0.045 & -0.050 & -0.058 & -0.020 & 1 & & & & & & & & & \\
\hline & 10 & -0.019 & 0.021 & -0.082 & -0.066 & -0.008 & -0.120 & $0.154 *$ & -0.028 & -0.051 & -0.085 & -0.048 & -0.024 & -0.032 & -0.035 & -0.041 & -0.014 & -0.035 & 1 & & & & & & & & \\
\hline & 11 & $-0.172 * *$ & -0.118 & -0.124 & $-0.149^{*}$ & -0.010 & -0.103 & -0.011 & -0.056 & -0.100 & $-0.169^{* * *}$ & $\begin{array}{l}-0.096 \\
\end{array}$ & -0.048 & -0.063 & -0.069 & -0.081 & -0.028 & -0.069 & -0.048 & 1 & & & & & & & \\
\hline & 12 & 0.094 & 0.083 & 0.101 & 0.052 & -0.036 & 0.060 & 0.012 & -0.044 & -0.079 & $-0.133^{*}$ & -0.075 & -0.038 & -0.049 & -0.054 & -0.063 & -0.022 & -0.054 & -0.038 & -0.075 & 1 & & & & & & \\
\hline & 13 & 0.007 & 0.017 & -0.053 & 0.039 & -0.017 & -0.025 & 0.037 & -0.016 & -0.029 & -0.049 & -0.028 & -0.014 & -0.018 & -0.020 & -0.023 & -0.008 & -0.020 & -0.014 & -0.028 & -0.022 & 1 & & & & & \\
\hline & 14 & -0.029 & -0.011 & -0.017 & 0.002 & -0.039 & -0.065 & -0.059 & $\begin{array}{l}-0.033 \\
\end{array}$ & -0.059 & -0.099 & -0.056 & -0.028 & -0.037 & -0.040 & -0.047 & -0.016 & -0.040 & -0.028 & -0.056 & -0.044 & -0.016 & 1 & & & & \\
\hline & 15 & -0.001 & 0.049 & 0.055 & $-0.141 *$ & -0.033 & -0.042 & -0.012 & -0.023 & -0.041 & -0.069 & -0.039 & -0.020 & -0.026 & -0.028 & -0.033 & -0.011 & -0.028 & -0.020 & -0.039 & -0.031 & -0.011 & -0.023 & 1 & & & \\
\hline & 16 & 0.030 & 0.053 & 0.112 & $0.297 * *$ & $0.243^{*} * *$ & -0.059 & $0.132^{*}$ & $\begin{array}{l}-0.028 \\
\end{array}$ & -0.051 & -0.085 & -0.048 & -0.024 & -0.032 & -0.035 & $-0.04 \cdot 1$ & -0.014 & -0.035 & -0.024 & -0.048 & -0.038 & -0.014 & -0.028 & -0.020 & 1 & & \\
\hline & 17 & 0.008 & 0.010 & 0.026 & $0.209^{* *}$ & $0.263^{* * *}$ & -0.054 & 0.055 & $\begin{array}{c}-0.023 \\
\end{array}$ & -0.041 & -0.069 & -0.039 & -0.020 & $\begin{array}{l}-0.026 \\
\end{array}$ & -0.028 & -0.033 & -0.011 & -0.028 & -0.020 & -0.039 & -0.031 & -0.011 & -0.023 & $\begin{array}{l}-0.016 \\
\end{array}$ & -0.020 & 1 & \\
\hline & 18 & -0.064 & -0.034 & -0.031 & 0.110 & -0.064 & $0.145^{*}$ & $-0.130 *$ & -0.047 & -0.084 & $-0.142^{*}$ & -0.081 & -0.041 & -0.053 & -0.058 & -0.068 & -0.023 & -0.058 & -0.041 & -0.081 & -0.063 & -0.023 & -0.047 & -0.033 & -0.041 & -0.033 & 1 \\
\hline
\end{tabular}


Firm size (SIZE) is measured as the log of total assets and has the same mean of 6.38 before and after the onset of the pandemic with a range of 5-9. Mean firm revenue (REV) before and after the pandemic was 1,039 and 974 million Riyals, respectively, with a range of -311 million to 33,690 million Riyals. Mean firm revenue (REV) thus fell by $6 \%$ following the onset of the pandemic. Firm liquidity has the same mean of 1.60 before and after the pandemic and ranges from 0.002 to 16.72 , and firm leverage (LEV) has the same mean of 0.46 before and after the COVID-19 pandemic with a range of 0.005 to 0.93. The ranking of industry groups by firm member numbers is as follows: Materials (others) (23\% of firms), followed by Materials (petrochemicals) (10\% of firms), Food \& Beverages and Capital Goods ( $9 \%$ of firms), Consumer Services, Health Care Equipment \& Services and Real Estate Management \& Development (6\% of firms), Consumer Durables \& Apparel and Retailing (5\% of firms), Transportation (4\% of firms), Energy and Diversified Financials (3\% of firms), Commercial \& Professional Services, Food \& Staples Retailing, Software \& Services, Telecommunication Services and Utilities (2\% of firms), and Media \& Entertainment and Pharma, Biotech \& Life Science (1\% of firms).

\subsection{Spearman Correlation Analysis}

Table 5 provides a Spearman rank correlation analysis of the model variables before the onset of the COVID-19 pandemic to identify any multicollinearity issues. For the dependent variables, ROA is significantly negatively correlated with firm leverage (LEV) (-0.171) and Food \& Beverages (-0.172). Further, ROE is significantly negatively associated with LEV (-0.205) and Capital Goods (-0.194). Furthermore, EPS is significantly negatively correlated with LEV (-0.225) and Capital Goods (-0.225). However, EPS is significantly positively associated with SIZE (0.256). Therefore, better accounting performance is generally associated with lower leverage, and performance in this area tends to be significantly worse in the Food \& Beverages and Capital Goods sectors. Better market performance tends to be enjoyed by larger firms, as we might expect.

Regarding the correlation between the independent variables, SIZE is significantly positively associated with both REV (0.577 and with LEV (0.332). In addition, SIZE is significantly positively associated with Materials (petrochemicals) (0.320) and Telecommunication Services (0.297). REV is also significantly positively associated with Telecommunication Services (0.243) and Utilities (0.263). LIQ is significantly negatively correlated with LEV (-0.545). In addition, LEV is significantly negatively associated with Materials (others) (-0.189). Thus, as expected, larger firms enjoy higher revenues and are more highly levered. Additionally, larger firms tend to be members of the petrochemicals and telecommunications industries. Those firms generating higher revenues tend to come from the telecommunications and utilities sectors, while firms in the materials industry are less highly levered.

Table 6 provides a Spearman rank correlation analysis of the model variables after the onset of the COVID-19 pandemic. For the dependent variables, ROA is significantly negatively correlated with LEV (-0.180) and Consumer Services (-0.201). ROE is significantly negatively associated with LEV (-0.224) and Consumer Durables \& Apparel (-0.218). Furthermore, EPS is significantly negatively correlated with LEV (-0.225) and Food \& Staples Retailing (0.487). However, EPS is significantly and positively associated with SIZE (0.207). We can see that following the onset of the pandemic, better accounting and market performances are associated with lower leverage, thereby illustrating the additional risk perceived by markets for more highly levered companies in times of financial difficulty. Further, all three performance measures appear significantly lower for the Consumer Services, Consumer Durables \& Apparel, and Food and Staples Retailing sectors.

Regarding the correlation between the independent variables, SIZE remains significantly positively associated with REV (0.592) and LEV (0.318). In addition, SIZE remains significantly positively associated with Materials (petrochemicals) (0.313) and Telecommunication Services (0.298). Further, REV remains significantly positively associated with Telecommunication Services (0.278) and Utilities (0.334). However, LIQ remains significantly negatively correlated with LEV (-0.577). In addition, LEV is significantly negatively associated with Materials (others) (-0.195), but also now with Food \& Staples Retailing (-0.205). 
Asian Economic and Financial Review, 2021, 11(9): 693-709

Table-6. Spearman correlation analysis after the Covid-19 pandemic

\begin{tabular}{|c|c|c|c|c|c|c|c|c|c|c|c|c|c|c|c|c|c|c|c|c|c|c|c|c|c|c|c|}
\hline & & \multirow{2}{*}{ ROA } & \multirow{2}{*}{ ROE } & \multirow{2}{*}{ EPS } & \multirow{2}{*}{ SIZE } & \multirow{2}{*}{ REV } & \multirow{2}{*}{ LIQ } & \multirow{2}{*}{ LEV } & \multicolumn{19}{|c|}{ Tadawul's Market Sectors - Industry Type } \\
\hline & & & & & & & & & 1 & 2.1 & 2.2 & 3 & 4 & 5 & 6 & 7 & 8 & 9 & 10 & 11 & 12 & 13 & 14 & 15 & 16 & 17 & 18 \\
\hline \multicolumn{2}{|c|}{ SIZE } & $.144 *$ & 0.094 & $.207 * * *$ & 1 & & & & & & & & & & & & & & & & & & & & & & \\
\hline \multicolumn{2}{|c|}{ REV } & 0.047 & 0.060 & 0.049 & $.592^{* * *}$ & 1 & & & & & & & & & & & & & & & & & & & & & \\
\hline \multicolumn{2}{|c|}{ LIQ } & 0.067 & 0.077 & 0.109 & $-.151 *$ & -0.081 & 1 & & & & & & & & & & & & & & & & & & & & \\
\hline \multicolumn{2}{|c|}{ LEV } & $-.180 * *$ & $-.224 * * *$ & $-.225 * *$ & $.318 * *$ & $.162^{*}$ & $-.577 * *$ & 1 & & & & & & & & & & & & & & & & & & & \\
\hline \multirow{2}{*}{ 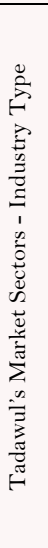 } & 1 & 0.020 & -0.034 & 0.037 & $.124 *$ & 0.063 & -0.013 & 0.077 & 1 & & & & & & & & & & & & & & & & & & \\
\hline \multirow{17}{*}{ 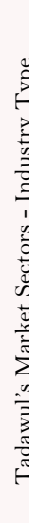 } & 2.1 & 0.016 & -0.011 & 0.027 & $.313^{* * *}$ & $.203 * * 3$ & -0.032 & -0.020 & -0.059 & 1 & & & & & & & & & & & & & & & & & \\
\hline & 2.2 & 0.120 & 0.097 & 0.058 & -0.120 & -0.112 & 0.062 & $-.195 * *$ & -0.099 & $-.177^{* * *}$ & 1 & & & & & & & & & & & & & & & & \\
\hline & 3 & $-.133^{*}$ & -0.12 & -0.05 & $-.157^{*}$ & -0.073 & -0.015 & 0.088 & -0.056 & -0.100 & $-.169 * *$ & 1 & & & & & & & & & & & & & & & \\
\hline & 4 & -0.02 & -0.02 & 0.081 & -0.034 & -0.036 & -0.026 & 0.066 & -0.028 & -0.051 & -0.085 & -0.048 & 1 & & & & & & & & & & & & & & \\
\hline & 5 & -0.072 & -0.041 & 0.019 & -0.001 & -0.048 & -0.004 & 0.016 & -0.037 & -0.066 & -0.111 & -0.063 & -0.032 & 1 & & & & & & & & & & & & & \\
\hline & 6 & -0.038 & $-.218 * *$ & -0.04 & $-.163^{* * *}$ & -0.060 & 0.071 & -0.064 & -0.040 & -0.073 & -0.122 & -0.069 & -0.035 & -0.045 & 1 & & & & & & & & & & & & \\
\hline & 7 & $-.201 * *$ & $-.153^{*}$ & 0.030 & -0.082 & -0.069 & -0.042 & 0.038 & -0.047 & -0.084 & $-.142^{*}$ & -0.081 & -0.041 & -0.053 & -0.058 & 1 & & & & & & & & & & & \\
\hline & 8 & 0.033 & 0.066 & 0.040 & 0.047 & -0.011 & -0.014 & 0.106 & -0.016 & -0.029 & -0.049 & -0.028 & -0.014 & -0.018 & -0.020 & -0.023 & 1 & & & & & & & & & & \\
\hline & 9 & $.148^{*}$ & .168 *** & 0.106 & -0.053 & -0.013 & -0.080 & 0.118 & -0.040 & -0.073 & -0.122 & -0.069 & -0.035 & -0.045 & -0.050 & -0.058 & -0.020 & 1 & & & & & & & & & \\
\hline & 10 & 0.022 & 0.041 & $-.487 * *$ & -0.068 & -0.004 & -0.116 & $.205 * * *$ & -0.028 & -0.051 & -0.085 & -0.048 & -0.024 & -0.032 & -0.035 & -0.041 & -0.014 & -0.035 & 1 & & & & & & & & \\
\hline & 11 & 0.005 & 0.046 & $\begin{array}{l}-0.072 \\
\end{array}$ & $-.140 *$ & -0.004 & -0.075 & -0.064 & -0.056 & -0.100 & $-.169 * *$ & -0.096 & -0.048 & -0.063 & -0.069 & -0.081 & \begin{tabular}{|c|}
-0.028 \\
\end{tabular} & $\begin{array}{l}-0.069 \\
-1\end{array}$ & -0.048 & 1 & & & & & & & \\
\hline & 12 & $.126^{*}$ & $\begin{array}{l}0.106 \\
\end{array}$ & 0.070 & 0.056 & -0.028 & 0.055 & 0.004 & -0.044 & \begin{tabular}{|c|}
-0.079 \\
\end{tabular} & $-.133^{*}$ & -0.075 & -0.038 & -0.049 & -0.054 & $\begin{array}{l}-0.063 \\
\end{array}$ & $\begin{array}{l}-0.022 \\
\end{array}$ & -0.054 & -0.038 & -0.075 & 1 & & & & & & \\
\hline & 13 & 0.019 & 0.027 & -0.040 & 0.038 & -0.017 & -0.031 & 0.044 & -0.016 & -0.029 & -0.049 & -0.028 & -0.014 & -0.018 & -0.020 & -0.023 & -0.008 & -0.020 & -0.014 & -0.028 & -0.022 & 1 & & & & & \\
\hline & 14 & -0.036 & -0.008 & -0.004 & 0.001 & -0.047 & $.204 * * *$ & -0.062 & -0.033 & -0.059 & -0.099 & -0.056 & -0.028 & -0.037 & -0.040 & -0.047 & -0.016 & -0.040 & -0.028 & -0.056 & -0.044 & -0.016 & 1 & & & & \\
\hline & 15 & -0.019 & 0.054 & 0.065 & $-.133^{*}$ & -0.033 & -0.032 & -0.014 & -0.023 & -0.041 & -0.069 & -0.039 & -0.020 & -0.026 & -0.028 & -0.033 & -0.011 & -0.028 & -0.020 & -0.039 & -0.031 & -0.011 & -0.023 & 1 & & & \\
\hline & 16 & 0.038 & 0.052 & 0.052 & $.298 * *$ & $.278 * *$ & -0.060 & 0.123 & -0.028 & -0.051 & -0.085 & -0.048 & -0.024 & -0.032 & -0.035 & -0.041 & - -0.014 & -0.035 & -0.024 & -0.048 & -0.038 & -0.014 & -0.028 & -0.020 & 1 & & \\
\hline & 17 & -0.003 & 0.015 & 0.006 & .210 *** & $.334 * *$ & -0.058 & 0.065 & -0.023 & -0.04 .1 & -0.069 & -0.039 & -0.020 & -0.026 & -0.028 & $\begin{array}{l}-0.033 \\
\end{array}$ & $\begin{array}{l}-0.011 \\
\end{array}$ & -0.028 & $\begin{array}{l}-0.020 \\
-\end{array}$ & $\begin{array}{l}-0.039 \\
-\end{array}$ & -0.031 & -0.011 & -0.023 & $\begin{array}{l}-0.016 \\
\end{array}$ & -0.020 & 1 & \\
\hline & 18 & -0.056 & -0.025 & -0.005 & 0.112 & -0.068 & 0.088 & -0.11 & -0.047 & -0.084 & $-.142^{*}$ & -0.081 & -0.041 & -0.053 & -0.058 & -0.068 & -0.023 & -0.058 & -0.041 & -0.081 & -0.063 & -0.023 & -0.047 & -0.033 & -0.041 & -0.033 & 1 \\
\hline
\end{tabular}

Source: Researchers' computation from SPSS

$* *=$ correlation is significant at the 0.01 level (2-tailed).
$*=$ correlation is significant at the 0.05 level $(2$-tailed). 
Thus, larger firms still enjoy higher revenues and are more highly levered following the onset of the pandemic. Further, larger firms are still those from the petrochemicals and telecommunications industries, while higher revenue firms remain those from the telecommunications and utilities sectors. Finally, food and staples retailing companies are now less highly levered. In common with the pre-pandemic period, more highly levered companies tend to have poorer liquidity.

\section{REGRESSION ANALYSIS}

\subsection{Operational Performance (ROA) Model I}

Table 7 presents the results of the multiple regression models (Model specification I) to determine the impact of firm characteristics during the COVID-19 pandemic on the operational performance (ROA) of Saudi listed firms. The operational performance $(R O A)$ model before the pandemic has an adjusted $R^{2}$ of 0.162 and a significant F-test $(\mathrm{F}=3.202, \mathrm{p}<0.001)$, while with the onset of the pandemic (hereafter labelled "after" for simplicity) the model has an adjusted $R^{2}$ of 0.134 and a significant $\mathrm{F}$-test $(\mathrm{F}=2.759, \mathrm{p}<0.001)$.

The results show evidence of some interesting variations in determinants when comparing the models before and after the onset of the pandemic. Operational performance (ROA) is significantly positively related to firm size (SIZE) both before and after the COVID-19 pandemic at the $1 \%$ level, providing support for hypothesis H1. Thus, larger firms tend to produce better operational performance than smaller firms in the presence and absence of the pandemic. Investment in a firm's fixed assets base (its productive capacity) clearly provides some protection when the business environment deteriorates, which is consistent with the recent empirical studies by Shen et al. (2020) and Song et al. (2021).

Operational performance (ROA) is significantly negatively related to firm leverage (LEV) before and after the pandemic at the $1 \%$ level, providing support for hypothesis $\mathrm{H} 4$. The result shows that more highly levered firms suffer a drop in operational performance regardless of the pandemic, though we might expect, and indeed observe, the effect to be exacerbated by the pandemic. External shocks, such as the pandemic, signal a potential increase in business risks and may lead to greater fixed costs due to changes in business operations (pandemic safety measures and changes to supply chains), thereby lowering operating profits. Agency conflicts may lead to firms becoming over-levered, thus reducing their operational performance in times of crisis, which is consistent with previous studies, such as Ding et al. (2020) and Song et al. (2021).

Revenue and liquidity remain insignificant both before and after the onset of the pandemic, suggesting that operational performance does not vary significantly with the different sales generation and liquidity management models employed by firms across different sectors. For example, sectors such as retailing may generate significant sales revenues on low margins and with minimal liquidity, while manufacturing firms may generate more modest revenues on higher margins and will maintain much higher liquidity to ensure continuity of business. The pandemic is unlikely to give rise to change in these sector-specific patterns.

The impact of industry type on operational performance is illustrated by the industry dummy variables. The Materials (petrochemicals), Food \& Beverages, and Real Estate Management \& Development sectors had significantly lower operational performance than other firms before the pandemic, providing support for hypothesis H5. The Commercial \& Professional Services and Retailing sectors had significantly higher operational performance than other firms before the pandemic, providing support for hypothesis $\mathrm{H} 5$, though the effect is weakened with the onset of the crisis. It is possible that operational performance suffers some compression across sectors, thereby leading to less distinction across sectors.

\subsection{Financial Performance (ROE) Model II}

Table 8 presents the results of the multiple regression models (Model specification II) to determine the impact of the COVID-19 pandemic on the financial performance $(R O E)$ of Saudi listed firms. The ROE model before the 
pandemic has an adjusted $R^{2}$ of 0.154 and a significant $\mathrm{F}$-test $(\mathrm{F}=3.071, \mathrm{p}<0.001)$, and with the onset of the pandemic it has an adjusted $R^{2}$ of 0.174 and a significant F-test $(\mathrm{F}=3.411, \mathrm{p}<0.001)$.

Table-7. Operational performance regression models before and after the Covid-19 pandemic.

\begin{tabular}{|c|c|c|c|c|c|c|c|}
\hline \multirow[t]{2}{*}{ Independent Variable } & \multirow[t]{2}{*}{ Definition } & \multicolumn{3}{|c|}{$\begin{array}{c}\text { Operational Performance } \\
\text { Model I (ROA) before } \\
\text { COVID-19 }\end{array}$} & \multicolumn{3}{|c|}{$\begin{array}{c}\text { Operational Performance } \\
\text { Model I (ROA) after } \\
\text { COVID-19 }\end{array}$} \\
\hline & & Coef. & t-statistic & $\mathbf{P}>\mathbf{t}$ & Coef. & t-statistic & $P>t$ \\
\hline Cons. & Model Constant & -0.062 & -3.425 & 0.001 & -0.058 & -2.685 & 0.008 \\
\hline$\overline{\text { SIZE }}$ & Firm size & 0.013 & 4.429 & 0.000 & 0.013 & 3.798 & 0.000 \\
\hline REV & Revenue & 0.000 & -1.074 & 0.284 & 0.000 & -1.236 & 0.218 \\
\hline LIQ & Liquidity & 0.001 & 1.263 & 0.208 & -0.001 & -0.786 & 0.433 \\
\hline LEV & Leverage & -0.029 & -3.889 & 0.000 & -0.039 & -4.267 & 0.000 \\
\hline Energy & Industry type & -0.010 & -1.210 & 0.228 & -0.003 & -0.278 & 0.782 \\
\hline Materials (petrochemicals) & Industry type & -0.018 & -3.266 & 0.001 & -0.011 & -1.667 & 0.097 \\
\hline Capital Goods & Industry type & -0.003 & -0.532 & 0.595 & -0.009 & -1.394 & 0.165 \\
\hline $\begin{array}{l}\text { Commercial \& } \\
\text { Svcs. }\end{array}$ & Industry type & 0.023 & 2.588 & 0.010 & -0.003 & -0.280 & 0.780 \\
\hline Transportation & Industry type & 0.000 & 0.016 & 0.987 & -0.014 & -1.575 & 0.117 \\
\hline Consumer Durables \& Apparel & Industry type & -0.010 & -1.498 & 0.135 & -0.005 & -0.605 & 0.546 \\
\hline Consumer Services & Industry type & 0.004 & 0.672 & 0.502 & -0.022 & -3.025 & 0.003 \\
\hline Media \& Entertainment & Industry type & 0.007 & 0.445 & 0.657 & 0.012 & 0.633 & 0.527 \\
\hline Retail & Industry type & 0.017 & 2.479 & 0.014 & 0.020 & 2.466 & 0.014 \\
\hline Food \& Staples Retail & Industry type & 0.006 & 0.645 & 0.520 & 0.015 & 1.308 & 0.192 \\
\hline Food \& Beverages & Industry type & -0.011 & -2.133 & 0.034 & -0.002 & -0.297 & 0.766 \\
\hline Health Care Equipment \& Svcs. & Industry type & 0.003 & 0.485 & 0.628 & 0.008 & 1.036 & 0.301 \\
\hline Pharma, Biotech \& Life Science & Industry type & -0.003 & -0.167 & 0.867 & 0.001 & 0.066 & 0.947 \\
\hline Diversified Financials & Industry type & -0.009 & -1.147 & 0.253 & -0.012 & -1.202 & 0.231 \\
\hline Software \& Services & Industry type & 0.006 & 0.543 & 0.588 & -0.001 & -0.041 & 0.967 \\
\hline Telecommunication Services & Industry type & -0.007 & -0.691 & 0.490 & -0.004 & -0.331 & 0.741 \\
\hline Utilities & Industry type & -0.009 & -0.801 & 0.424 & -0.009 & -0.643 & 0.521 \\
\hline Real Estate Mgmt \& Dev't & Industry type & -0.018 & -2.931 & 0.004 & -0.018 & -2.469 & 0.014 \\
\hline \multicolumn{2}{|l|}{ Adjusted R-squared } & \multicolumn{3}{|c|}{0.162} & \multicolumn{3}{|c|}{0.134} \\
\hline \multicolumn{2}{|l|}{ F-Statistic } & \multicolumn{3}{|c|}{3.202} & \multicolumn{3}{|c|}{2.759} \\
\hline \multicolumn{2}{|l|}{ VIF } & \multicolumn{3}{|c|}{$<2.5$} & \multicolumn{3}{|c|}{$<2.5$} \\
\hline \multicolumn{2}{|l|}{ Prob. $(\mathrm{F})$} & \multicolumn{3}{|c|}{$\mathrm{O}$} & \multicolumn{3}{|c|}{$\mathrm{O}$} \\
\hline \multicolumn{2}{|l|}{ No. of observations } & \multicolumn{3}{|c|}{126} & \multicolumn{3}{|c|}{126} \\
\hline
\end{tabular}

Financial performance $(R O E)$ is significantly positively related to firm size (SIZE) both before and after COVID-19 pandemic at the $1 \%$ and $10 \%$ levels, providing support for hypothesis $\mathrm{H} 1$. Thus, larger firms generate better financial performance than smaller firms over the period, employing the funds raised from equity more effectively, though the effect weakens somewhat with the onset of the pandemic. While larger firms are to some extent more insulated from the pandemic (Shen et al., 2020; Song et al., 2021) and enjoy more significant equity cushions, they are far from totally protected.

Financial performance $(R O E)$ is significantly negatively related to firm leverage ( $L E V$ ) before and after the pandemic at the $1 \%$ level, providing support for hypothesis H4. In common with operational performance, the result shows that more highly levered firms suffer from lower returns on investor equity regardless of the pandemic, and eventually such firms may be far less able to cope with the increased business risk brought by the pandemic in conjunction with the financial risk inherent in their capital structures. It may take some time for this effect to work through the financial statement figures to provide results consistent with authors such as Ding et al. (2020) and Song et al. (2021).

As in the operational performance model, revenue and liquidity appear not to be significant drivers of financial performance as different sectors are characterized by different sales generation and liquidity management models. 
Turning to the impact of industry type on financial performance, significantly better performance is associated with membership of the Retailing and Commercial \& Professional Services sectors before the pandemic, providing support for hypothesis $\mathrm{H} 5$, an effect which persists with the onset of the pandemic in the former though it dissipates in the latter. Further, Food \& Staples Retailing exhibits better financial performance than other sectors following the pandemic, as such, expenditure is regarded as essential and is thus not limited by government policy and actions. However, the Consumer Durables \& Apparel, Consumer Services, and Real Estate Management \& Development sectors all become significantly worse performers than other sectors with the onset of the pandemic. Clearly investing in property, engaging with consumer service providers, and investing in consumer durables are all decisions that many consumers will postpone in the face of such a crisis.

Table-8. Financial performance regression before and after the Covid-19 pandemic

\begin{tabular}{|c|c|c|c|c|c|c|c|}
\hline \multirow[t]{2}{*}{ Independent Variable } & \multirow[t]{2}{*}{ Definition } & \multicolumn{3}{|c|}{$\begin{array}{c}\text { Financial Performance } \\
\text { Model II (ROE) before } \\
\text { COVID-19 }\end{array}$} & \multicolumn{3}{|c|}{$\begin{array}{c}\text { Financial Performance } \\
\text { Model II (ROE) after } \\
\text { COVID-19 }\end{array}$} \\
\hline & & Coef. & t-statistic & $\mathbf{P}>\mathbf{t}$ & Coef. & t-statistic & $\mathbf{P}>\mathbf{t}$ \\
\hline Cons. & Model Constant & -0.133 & -2.603 & 0.010 & -0.100 & -1.697 & 0.091 \\
\hline SIZE & Firm size & 0.029 & 3.464 & 0.001 & 0.026 & 2.747 & 0.006 \\
\hline REV & Revenue & 0.000 & -0.480 & 0.632 & 0.000 & -0.390 & 0.697 \\
\hline LIQ & Liquidity & 0.000 & -0.036 & 0.971 & -0.003 & -1.009 & 0.314 \\
\hline LEV & Leverage & -0.103 & -4.859 & 0.000 & -0.126 & -5.097 & 0.000 \\
\hline Energy & Industry type & -0.013 & -0.587 & 0.558 & -0.020 & -0.750 & 0.454 \\
\hline Materials (petrochemicals) & Industry type & -0.025 & -1.583 & 0.115 & -0.028 & -1.555 & 0.121 \\
\hline Capital Goods & Industry type & -0.022 & -1.450 & 0.149 & -0.018 & -1.037 & 0.301 \\
\hline Commercial \& Professional Svcs. & Industry type & 0.071 & 2.758 & 0.006 & -0.001 & -0.037 & 0.971 \\
\hline Transportation & Industry type & 0.010 & 0.497 & 0.620 & -0.020 & -0.843 & 0.400 \\
\hline Consumer Durables \& Apparel & Industry type & -0.010 & -0.523 & 0.601 & -0.074 & -3.368 & 0.001 \\
\hline Consumer Services & Industry type & 0.024 & 1.422 & 0.157 & -0.042 & -2.151 & 0.033 \\
\hline Media \& Entertainment & Industry type & 0.071 & 1.643 & 0.102 & 0.075 & 1.497 & 0.136 \\
\hline Retailing & Industry type & 0.062 & 3.237 & 0.001 & 0.068 & 3.080 & 0.002 \\
\hline Food \& Staples Retailing & Industry type & 0.043 & 1.637 & 0.103 & 0.057 & 1.862 & 0.064 \\
\hline Food \& Beverages & Industry type & -0.014 & -0.950 & 0.343 & 0.005 & 0.296 & 0.767 \\
\hline Health Care Equipment \& Svcs. & Industry type & 0.020 & 1.131 & 0.259 & 0.024 & 1.146 & 0.253 \\
\hline Pharma, Biotech \& Life Science & Industry type & 0.015 & 0.347 & 0.729 & 0.021 & 0.434 & 0.665 \\
\hline Diversified Financials & Industry type & -0.011 & -0.489 & 0.625 & -0.015 & -0.559 & 0.577 \\
\hline Software \& Services & Industry type & 0.046 & 1.462 & 0.145 & 0.039 & 1.101 & 0.272 \\
\hline Telecommunication Services & Industry type & 0.010 & 0.357 & 0.721 & 0.009 & 0.296 & 0.767 \\
\hline Utilities & Industry type & -0.011 & -0.329 & 0.743 & -0.009 & -0.224 & 0.823 \\
\hline Real Estate Mgmt \& Dev't & Industry type & -0.028 & -1.614 & 0.108 & -0.033 & -1.668 & 0.097 \\
\hline \multicolumn{2}{|l|}{ Adjusted R-squared } & \multicolumn{3}{|c|}{0.154} & \multicolumn{3}{|c|}{0.174} \\
\hline \multicolumn{2}{|l|}{ F-Statistic } & \multicolumn{3}{|c|}{3.071} & \multicolumn{3}{|c|}{3.411} \\
\hline \multicolumn{2}{|l|}{ VIF } & \multicolumn{3}{|c|}{$<2.5$} & \multicolumn{3}{|c|}{$<2.5$} \\
\hline \multicolumn{2}{|l|}{ Prob. $(\mathrm{F})$} & \multicolumn{3}{|c|}{$\mathrm{O}$} & \multicolumn{3}{|c|}{$\mathrm{O}$} \\
\hline \multicolumn{2}{|l|}{ No. of observations } & \multicolumn{3}{|c|}{126} & \multicolumn{3}{|c|}{126} \\
\hline
\end{tabular}

\subsection{Market Performance (EPS) Model III}

Table 9 presents the results of the multiple regression models (Model specification III) to determine the impact of the COVID-19 pandemic on the market performance (EPS) of Saudi listed firms. The market performance (EPS) model before the pandemic has an adjusted $\mathrm{R}^{2}$ of 0.312 and a significant $\mathrm{F}$-test $(\mathrm{F}=6.163, \mathrm{p}<0.001)$, and with the onset of the pandemic the mode has an adjusted $\mathrm{R}^{2}$ of 0.321 and a significant $\mathrm{F}$-test $(\mathrm{F}=6.388, \mathrm{p}<0.001)$.

In common with the previous models, market performance (EPS) is significantly positively related to firm size (SIZE) both before and after the COVID-19 pandemic at the 1\% level, providing support for hypothesis H1. Thus, larger firms tend to provide better earnings to shareholders throughout the period, regardless of the pandemic, 
which is consistent with Shen et al. (2020) and Song et al. (2021). If anything, the coefficient shows that the effect is strengthened as larger firms have more predictable and diversified earnings streams than smaller firms.

Market performance (EPS) is significantly negatively related to leverage (LEV) before and after the pandemic at the $1 \%$ level, providing support for hypothesis $\mathrm{H} 4$. The result shows that firms with high leverage signal to investors a possible rise in business uncertainty, evoking anxiety among investors and contributing to stock market falls as the business environment deteriorates (Ding et al., 2020). Certainly, a global pandemic is probably the worst business environment shock that investors might imagine, and they will be aware that heightened financial risk may be compounded by greater business risk. This finding is consistent with existing studies (Ding et al., 2020; Song et al., 2021).

Table-9. Market performance regression models before and after the Covid-19 pandemic.

\begin{tabular}{|c|c|c|c|c|c|c|c|}
\hline \multirow[t]{2}{*}{ Independent Variable } & \multirow[t]{2}{*}{ Definition } & \multicolumn{3}{|c|}{$\begin{array}{l}\text { Market Performance } \\
\text { Model III (EPS) before } \\
\text { COVID-19 }\end{array}$} & \multicolumn{3}{|c|}{$\begin{array}{l}\text { Market Performance } \\
\text { Model III (EPS) after } \\
\text { COVID-19 }\end{array}$} \\
\hline & & Coef. & t-statistic & $\mathbf{P}>\mathbf{t}$ & Coef. & $\begin{array}{c}\mathrm{t}- \\
\text { statistic }\end{array}$ & $\mathbf{P}>\mathbf{t}$ \\
\hline Cons. & Model Constant & -7.035 & -3.341 & 0.001 & -18.281 & -4.263 & 0.000 \\
\hline SIZE & Firm size & 1.511 & 4.401 & 0.000 & 3.604 & 5.132 & 0.000 \\
\hline REV & Revenue & 0.000 & 0.622 & 0.534 & 0.000 & -1.543 & 0.124 \\
\hline LIQ & Liquidity & -0.077 & -0.724 & 0.470 & -0.163 & -0.787 & 0.432 \\
\hline LEV & Leverage & -5.752 & -6.556 & 0.000 & -8.216 & -4.542 & 0.000 \\
\hline Energy & Industry type & 0.989 & 1.047 & 0.296 & 0.221 & 0.115 & 0.909 \\
\hline Materials (petrochemicals) & Industry type & 0.266 & 0.414 & 0.679 & -2.024 & -1.556 & 0.121 \\
\hline Capital Goods & Industry type & -0.803 & -1.265 & 0.207 & 0.376 & 0.292 & 0.771 \\
\hline $\begin{array}{l}\text { Commercial \& Professional } \\
\text { Svcs. }\end{array}$ & Industry type & 4.446 & 4.193 & 0.000 & 3.916 & 1.816 & 0.071 \\
\hline Transportation & Industry type & 1.198 & 1.428 & 0.155 & 0.204 & 0.119 & 0.906 \\
\hline Consumer Durables \& Apparel & Industry type & -1.661 & -2.102 & 0.037 & -0.270 & -0.168 & 0.866 \\
\hline Consumer Services & Industry type & 1.348 & 1.931 & 0.055 & 1.176 & 0.827 & 0.409 \\
\hline Media \& Entertainment & Industry type & 3.493 & 1.951 & 0.052 & 3.269 & 0.900 & 0.369 \\
\hline Retailing & Industry type & 3.419 & 4.296 & 0.000 & 3.975 & 2.459 & 0.015 \\
\hline Food \& Staples Retailing & Industry type & 0.552 & 0.509 & 0.611 & -15.714 & -7.009 & 0.000 \\
\hline Food \& Beverages & Industry type & -0.379 & -0.606 & 0.545 & -1.146 & -0.905 & 0.367 \\
\hline Health Care Equipment \& Svcs. & Industry type & 1.507 & 2.038 & 0.043 & 0.812 & 0.541 & 0.589 \\
\hline Pharma, Biotech \& Life Science & Industry type & -1.278 & -0.723 & 0.471 & -3.400 & -0.944 & 0.346 \\
\hline Diversified Financials & Industry type & -0.371 & -0.400 & 0.690 & -1.028 & -0.534 & 0.594 \\
\hline Software \& Services & Industry type & 2.690 & 2.089 & 0.038 & 4.846 & 1.854 & 0.065 \\
\hline Telecommunication Services & Industry type & 1.414 & 1.246 & 0.214 & -0.531 & -0.228 & 0.820 \\
\hline Utilities & Industry type & -0.449 & -0.335 & 0.738 & -1.636 & -0.586 & 0.558 \\
\hline Real Estate Mgmt \& Dev't & Industry type & -0.994 & -1.388 & 0.166 & -2.467 & -1.703 & 0.090 \\
\hline \multicolumn{2}{|l|}{ Adjusted R-squared } & \multicolumn{3}{|c|}{0.312} & \multicolumn{3}{|c|}{0.321} \\
\hline \multicolumn{2}{|l|}{ F-Statistic } & \multicolumn{3}{|c|}{6.163} & \multicolumn{3}{|c|}{6.388} \\
\hline \multicolumn{2}{|l|}{$\mathrm{VIF}$} & \multicolumn{3}{|c|}{$<2.5$} & \multicolumn{3}{|c|}{$<2.5$} \\
\hline \multicolumn{2}{|l|}{ Prob. $(\mathrm{F})$} & \multicolumn{3}{|c|}{$\mathrm{O}$} & \multicolumn{3}{|c|}{$\mathrm{O}$} \\
\hline \multicolumn{2}{|l|}{ No. of observations } & \multicolumn{3}{|c|}{126} & \multicolumn{3}{|c|}{126} \\
\hline
\end{tabular}

In common with the two accounting performance measure models above, liquidity and revenue have little observable impact on market performance given the wide range of sales generation and liquidity management models that apply across sectors.

In terms of the impact of industry type, before the pandemic, the following sectors significantly outperformed other sectors in terms of EPS, which provides support for hypothesis H5: Commercial \& Professional Services, Consumer Services, Media \& Entertainment, Retailing, Health Care Equipment \& Services, and Software \& Services. However, the pandemic brought with it compression in earnings and therefore the effect was reduced or 
dissipated in some of these sectors as earnings struggled to outperform on a per share basis. Sectors which significantly underperformed on EPS include Consumer Durables \& Apparel before the pandemic and Real Estate Management \& Development with the onset of the pandemic. Again, some sectors are less robust to economic shocks than others, with consumers, for example, delaying investment in property and the business property market taking a huge hit with the introduction of lockdown measures.

\subsection{Models Including the COVID-19 Dummy Variable (Models IV-VI)}

Tables 10 to 12 show the results of the three models which examine the impact of the COVID-19 pandemic on the three performance measures of operational performance (ROA), financial performance (ROE), and market performance (EPS), respectively. The models clearly provide qualitatively very similar results to Models I to III in terms of the four main independent variables, with size (SIZE) a significant positive driver and leverage (LEV) a significant negative driver of performance across the three measures. In addition, industry type significantly varies across the three measures. Again, sales revenue and liquidity are not significant drivers of performance across the three models.

Table-10. Operational performance regression model for whole sample including a Covid-19 pandemic dummy.

\begin{tabular}{|c|c|c|c|c|}
\hline \multirow{2}{*}{ Independent Variable } & \multirow{2}{*}{ Definition } & \multicolumn{3}{|c|}{ Operational Performance Model IV (ROA) } \\
\hline & & Coef. & t-statistic & $\mathbf{P}>\mathbf{t}$ \\
\hline Cons. & Model Constant & -0.059 & -4.153 & 0.000 \\
\hline SIZE & Firm size & 0.013 & 5.748 & 0.000 \\
\hline REV & Revenue & 0.000 & -1.592 & 0.112 \\
\hline LIQ & Liquidity & 0.000 & 0.164 & 0.870 \\
\hline LEV & Leverage & -0.034 & -5.839 & 0.000 \\
\hline Energy & Industry type & -0.006 & -0.967 & 0.334 \\
\hline Materials (petrochemicals) & Industry type & -0.014 & -3.347 & 0.001 \\
\hline Capital Goods & Industry type & -0.006 & -1.365 & 0.173 \\
\hline Commercial \& Professional Svcs. & Industry type & 0.010 & 1.453 & 0.147 \\
\hline Transportation & Industry type & -0.007 & -1.202 & 0.230 \\
\hline Consumer Durables \& Apparel & Industry type & -0.007 & -1.373 & 0.170 \\
\hline Consumer Services & Industry type & -0.009 & -1.867 & 0.063 \\
\hline Media \& Entertainment & Industry type & 0.009 & 0.790 & 0.430 \\
\hline Retailing & Industry type & 0.018 & 3.479 & 0.001 \\
\hline Food \& Staples Retailing & Industry type & 0.010 & 1.398 & 0.163 \\
\hline Food \& Beverages & Industry type & -0.007 & -1.595 & 0.111 \\
\hline Health Care Equipment \& Svcs. & Industry type & 0.006 & 1.119 & 0.264 \\
\hline Pharma, Biotech \& Life Science & Industry type & -0.001 & -0.051 & 0.959 \\
\hline Diversified Financials & Industry type & -0.012 & -1.888 & 0.060 \\
\hline Software \& Services & Industry type & 0.003 & 0.310 & 0.757 \\
\hline Telecommunication Services & Industry type & -0.005 & -0.704 & 0.482 \\
\hline Utilities & Industry type & -0.009 & -1.039 & 0.300 \\
\hline Real Estate Mgmt \& Dev't & Industry type & -0.018 & -3.731 & 0.000 \\
\hline After COVID-19 & Period & -0.002 & -1.082 & 0.280 \\
\hline \multicolumn{2}{|l|}{ Adjusted R-squared } & \multicolumn{3}{|c|}{0.143} \\
\hline \multicolumn{2}{|l|}{ F-Statistic } & \multicolumn{3}{|c|}{4.653} \\
\hline \multicolumn{2}{|l|}{ VIF } & \multicolumn{3}{|c|}{$<2.5$} \\
\hline \multicolumn{2}{|l|}{ Prob. $(\mathrm{F})$} & \multicolumn{3}{|c|}{$\mathrm{O}$} \\
\hline \multicolumn{2}{|l|}{ No. of observations } & \multicolumn{3}{|c|}{126} \\
\hline
\end{tabular}

Focusing specifically on the dummy variable capturing the onset of the COVID-19 pandemic (COVID) as 1 versus 0 before the pandemic, we test the direct impact of the pandemic on the three performance measures. Surprisingly, while the impact is clearly negative across the three measures, the impact is not significant at conventional levels. 
There are a number of reasons why this might be the case. First, this paper only captures two quarters before and after the onset of the pandemic given that we are still in the early stages of the pandemic, and therefore it is possible that the full effects of the crisis have yet to feed through significantly. For example, supply chains and order books are agreed many months in advance for most firms, and therefore the impact on profits is likely to be muted initially. Second, the models capture the average impact of the crisis across sectors and it may be that the true impact will only be observed at the micro level with certain individual sectors or even subsectors performing particularly badly whilst others thrive with the accompanying market distortions. Third, it is likely that the full impact will only be observed with annual data spanning a number of years before and after the onset of the pandemic, as firms may use earnings management tools within a given financial year.

Table-11. Financial performance regression model for whole sample including a Covid-19 pandemic dummy.

\begin{tabular}{|c|c|c|c|c|}
\hline \multirow{2}{*}{ Independent Variables } & \multirow{2}{*}{ Definition } & \multicolumn{3}{|c|}{ Financial Performance Model V (ROE) } \\
\hline & & Coef. & t-statistic & $\mathbf{P}>\mathbf{t}$ \\
\hline Cons. & Model Constant & -0.115 & -2.969 & 0.003 \\
\hline $\mathrm{SIZE}$ & Firm size & 0.028 & 4.393 & 0.000 \\
\hline REV & Revenue & 0.000 & -0.585 & 0.559 \\
\hline $\mathrm{LIQ}$ & Liquidity & -0.001 & -0.700 & 0.484 \\
\hline $\mathrm{LEV}$ & Leverage & -0.115 & -7.082 & 0.000 \\
\hline Energy & Industry type & -0.017 & -0.955 & 0.340 \\
\hline Materials (petrochemicals) & Industry type & -0.026 & -2.221 & 0.027 \\
\hline Capital Goods & Industry type & -0.020 & -1.719 & 0.086 \\
\hline Commercial \& Professional Svcs. & Industry type & 0.035 & 1.793 & 0.074 \\
\hline Transportation & Industry type & -0.005 & -0.328 & 0.743 \\
\hline Consumer Durables \& Apparel & Industry type & -0.042 & -2.870 & 0.004 \\
\hline Consumer Services & Industry type & -0.009 & -0.678 & 0.498 \\
\hline Media \& Entertainment & Industry type & 0.073 & 2.218 & 0.027 \\
\hline Retailing & Industry type & 0.066 & 4.467 & 0.000 \\
\hline Food \& Staples Retailing & Industry type & 0.050 & 2.478 & 0.014 \\
\hline Food \& Beverages & Industry type & -0.004 & -0.379 & 0.705 \\
\hline Health Care Equipment \& Svcs. & Industry type & 0.022 & 1.606 & 0.109 \\
\hline Pharma, Biotech \& Life Science & Industry type & 0.018 & 0.557 & 0.578 \\
\hline Diversified Financials & Industry type & -0.015 & -0.872 & 0.384 \\
\hline Software \& Services & Industry type & 0.043 & 1.801 & 0.072 \\
\hline Telecommunication Services & Industry type & 0.009 & 0.446 & 0.656 \\
\hline Utilities & Industry type & -0.010 & -0.404 & 0.687 \\
\hline Real Estate Mgmt \& Dev't & Industry type & -0.031 & -2.326 & 0.020 \\
\hline After COVID 19 & Period & -0.005 & -0.936 & 0.350 \\
\hline \multicolumn{2}{|l|}{ Adjusted R-squared } & \multicolumn{3}{|c|}{0.169} \\
\hline \multicolumn{2}{|l|}{ F-Statistic } & \multicolumn{3}{|c|}{5.453} \\
\hline \multicolumn{2}{|l|}{ VIF } & \multicolumn{3}{|c|}{$<2.5$} \\
\hline \multicolumn{2}{|l|}{ Prob. (F) } & \multicolumn{3}{|c|}{$\mathrm{O}$} \\
\hline \multicolumn{2}{|l|}{ No. of observations } & \multicolumn{3}{|c|}{126} \\
\hline
\end{tabular}

\section{CONCLUSION}

This study aimed to examine impact of firm characteristics on the operational, financial, and market performance of Saudi listed firms during the COVID-19 pandemic. The paper applied both descriptive multiple regression analyses to data collected from 504 quarterly reports over the period from Q3 2019 to Q3 2020, thereby examining two quarters before and after the onset of the pandemic.

The descriptive analysis illustrates that the operational, financial, and market performance measures all saw a significant drop with the onset of the pandemic, thus providing some preliminary evidence in support of this study's hypotheses. At the level of the Saudi economy, many firms saw a significant impact as consumer and business spending were reduced due to the imposition of lockdowns, forced business closures, and other measures which restricted expenditure in the economy. While the scale of firms remained steady in terms of quarterly data, annual 
data over subsequent years will most likely show a reduction in firm size as equity bases are eroded through cumulative losses and the need to downsize less viable business operations. Revenues were hit particularly sharply in certain industries, and overall, as consumer and business expenditure fell. However, firm leverage and liquidity statistics showed little change over the study period as these are relative measures and may be kept fairly stable through careful firm financial management.

Table-12. Market performance regression model for whole sample including a Covid-19 pandemic dummy.

\begin{tabular}{|c|c|c|c|c|}
\hline \multirow{2}{*}{ Independent Variable } & \multirow{2}{*}{ Definition } & \multicolumn{3}{|c|}{ Market Performance Model VI (EPS) } \\
\hline & & Coef. & t-statistic & $P>t$ \\
\hline Cons. & Model Constant & -12.607 & -5.051 & 0.000 \\
\hline$\overline{\mathrm{SIZE}}$ & Firm size & 2.577 & 6.330 & 0.000 \\
\hline REV & Revenue & 0.000 & -1.015 & 0.311 \\
\hline LIQ & Liquidity & -0.127 & -1.042 & 0.298 \\
\hline$\overline{\mathrm{LEV}}$ & Leverage & -7.216 & -6.936 & 0.000 \\
\hline Energy & Industry type & 0.645 & 0.577 & 0.564 \\
\hline Materials (petrochemicals) & Industry type & -0.886 & -1.169 & 0.243 \\
\hline Capital Goods & Industry type & -0.170 & -0.227 & 0.821 \\
\hline Commercial \& Professional Svcs. & Industry type & 4.220 & 3.360 & 0.001 \\
\hline Transportation & Industry type & 0.717 & 0.720 & 0.472 \\
\hline Consumer Durables \& Apparel & Industry type & -0.954 & -1.022 & 0.307 \\
\hline Consumer Services & Industry type & 1.284 & 1.553 & 0.121 \\
\hline Media \& Entertainment & Industry type & 3.474 & 1.640 & 0.102 \\
\hline Retailing & Industry type & 3.744 & 3.975 & 0.000 \\
\hline Food \& Staples Retailing & Industry type & -7.568 & -5.847 & 0.000 \\
\hline Food \& Beverages & Industry type & -0.727 & -0.983 & 0.326 \\
\hline Health Care Equipment \& Svcs. & Industry type & 1.179 & 1.347 & 0.179 \\
\hline Pharma, Biotech \& Life Science & Industry type & -2.320 & -1.107 & 0.269 \\
\hline Diversified Financials & Industry type & -0.749 & -0.682 & 0.496 \\
\hline Software \& Services & Industry type & 3.812 & 2.502 & 0.013 \\
\hline Telecommunication Services & Industry type & 0.398 & 0.296 & 0.768 \\
\hline Utilities & Industry type & -1.203 & -0.750 & 0.453 \\
\hline Real Estate Mgmt \& Dev't & Industry type & -1.740 & -2.059 & 0.040 \\
\hline After COVID-19 & Period & -0.156 & -0.427 & 0.670 \\
\hline \multicolumn{2}{|l|}{ Adjusted R-squared } & \multicolumn{3}{|c|}{0.255} \\
\hline \multicolumn{2}{|l|}{ F-Statistic } & \multicolumn{3}{|c|}{8.489} \\
\hline \multicolumn{2}{|l|}{ VIF } & \multicolumn{3}{|c|}{$<2.5$} \\
\hline \multicolumn{2}{|l|}{ Prob. $(\mathrm{F})$} & \multicolumn{3}{|c|}{$\mathrm{O}$} \\
\hline \multicolumn{2}{|l|}{ No. of observations } & \multicolumn{3}{|c|}{126} \\
\hline
\end{tabular}

The multiple regression analyses consisted of two modelling approaches: first, models (I-III) to capture the drivers of performance before and after the onset of the pandemic; and second, models (IV-VI) to capture the impact of the scale of the pandemic on firm performance. The first set of models of operational (ROA), financial (ROE), and market performance (EPS) show that larger firms produce better performance both before and after the pandemic, though there is some evidence of a weakening of this relation for ROE with the onset of the pandemic. Larger firms are more protected from the pandemic shock due to greater reserves, more visible order books, stronger supply chains, and more diversified customer bases and distribution networks, though these may be eroded the longer the effects of the shock persist. Leverage is a negative driver of firm performance across the three measures both before and after the onset of the pandemic, though there is evidence that the effect strengthens after the crisis as the total risk is increased by highly levered firms suffering greater financial risk. Neither sales revenue scale nor firm liquidity exert a significant impact on the three performance measures, probably as the regression models capture average behavior, whereas different sectors are characterized by different sales generation and liquidity management models whose relationship with performance may only be visible at the disaggregated (micro) level. 
The impact of the COVID-19 pandemic on different industries may also be inferred by observing the relationship between the performance measures and industry type before and after the onset of the pandemic. Those industries performing worse than others before the pandemic included Materials (petrochemicals), Food \& Beverages, and Real Estate Management \& Development sectors, though following the onset of the pandemic this effect weakened. Industries performing significantly worse with the onset of the pandemic included Consumer Durables \& Apparel, Consumer Services and Real Estate Management \& Development. However, industries performing better than others before the pandemic include Commercial \& Professional Services, Retailing, Consumer Services, Media \& Entertainment, Health Care Equipment \& Services, and Software \& Services, though the superior performance of many of these industries was reduced or had completely disappeared with the onset of the pandemic. We may infer that the onset of the pandemic brought with it a very different business environment, with earnings compression across most industries; the effect of this was to narrow the performance metric range of both outperforming and underperforming industries. The list of target industries for investors has clearly changed, with sectors requiring longer term business or consumer investments, such as real estate or consumer durables evidently performing very badly since the onset of the pandemic. However, more defensive industries, such as food and staples, that provide for the basic needs of consumers will most likely continue to perform well, as will industries such as software and related services which provide business and consumer infrastructure to enable the economy to continue within the challenging pandemic environment. Overall, we can clearly observe the very varied impact of the COVID-19 pandemic on firm performance across industries, and thus we find support for hypothesis H5.

The second set of multiple regression models was introduced to specifically test the hypothesis that the pandemic has a significant impact on the three measures of firm performance with the introduction of a dummy variable signifying the onset of the pandemic. Surprisingly, we find that the dummy is insignificant across the three measures (ROA, ROE, and EPS). We argue, however, that the result may be explained by the limited window of data available following the onset of the crisis, the aggregation effect of modelling the whole sample rather than individual industries at the micro level, and the potential employment of earnings management techniques by firms to smooth earnings within a given year. Thus, while the descriptive analysis provides support for hypothesis $\mathrm{H} 1$, the modelling exercise reveals the situation to be more complex and worthy of further micro-level investigation. Thus, there remains some weak support for the hypothesis. From the perspective of COVID-19 prevention in Saudi Arabia, the countermeasures have successfully reduced its spread. However, at the same time, economic production and consumption remain restricted, leading to a weak economy and continuing poor corporate performance. Fortunately, the impact should be reduced in both scale and timeframe under Saudi government countermeasures, such as fiscal stimulus packages for workers and businesses. The negative impact of the pandemic on the global economy is unprecedented, while the focus remains less on economic impacts and more on the necessity for control and prevention at this juncture. Looking at firm performance, there are significant variations across industries with the onset of the pandemic. Key industries such as petrochemicals, consumer services, real estate, and consumer durables \& apparel, suffer significantly from the pandemic's impact. In addition, to control and prevent the spread of COVID-19, governments may need to focus more on supporting those industries most seriously impacted by means of special programs to help them weather the storm with less damage. The results of this study have wide implications for decision-makers. Clearly, regulatory bodies, governments, and central banks should combine forces to soften the financial and economic impacts of the pandemic. Comprehensive policies are essential to deal with the negative impact of not only the current but also future crises of this type in the interest of business sustainability. Credit insurance provision and the rescheduling of current loans to the worst-hit industry sectors are a starting point. The development of COVID-19 vaccines, along with the transparent disclosure of official statistics on health care status and the number of infections may minimize the likelihood of potential future crises in addition to their financial and economic impacts. 
Funding: This study received no specific financial support.

Competing Interests: The authors declare that they have no competing interests.

Acknowledgement: All authors contributed equally to the conception and design of the study.

\section{REFERENCES}

Bagnera, S., \& Steinberg, M. (2020). Sanitized practices for human resources in a COVID-19 environment. Boston Hospitality Reviere, 2020 - April(Issue Special Edition: Covid-19 Crisis), 1-8.

Coronavirus Update. (2021). Worldometers.info/coronavirus/. Retrieved from https://www.worldometers.info/coronavirus/. [Accessed 25 January 2021].

Ding, W., Levine, R., Lin, C., \& Xie, W. (2020). Corporate immunity to the COVID-19 pandemic. Working Paper.

Fu, M., \& Shen, H. (2020). COVID-19 and corporate performance in the energy industry. Energy Research Letters, 1(1), 1-5. Available at: https://doi.org/10.46557/001c.12967.

Hagerty, S. L., \& Williams, L. M. (2020). The impact of COVID-19 on mental health: The interactive roles of brain biotypes and human connection. Brain, Behavior, \& Immunity-Health, 5, 100078. Available at: https://doi.org/10.1016/j.bbih.2020.100078.

Havrlant, D., Darandary, A., \& Muhsen, A. (2020). Early estimates of the impact of the COVID-19 pandemic on GDP: A case study of Saudi Arabia. Applied Economics, 53(12), 1317-1325. Available at: https://doi.org/10.1080/00036846.2020.1828809.

Iyke, B. N. (2020). COVID-19: The reaction of US oil and gas producers to the pandemic. Energy Research Letters, 1(2), 1-7. Available at: https://doi.org/10.46557/001c.13912.

Liu, L., Wang, E.-Z., \& Lee, C.-C. (2020). Impact of the COVID-19 pandemic on the crude oil and stock markets in the US: A time-varying analysis. Energy Research Letters, 1(1), 1-5. Available at: https://doi.org/10.46557/001c.13154.

Narayan, P. K. (2020). Oil price news and COVID-19-is there any connection? Energy Research Letters, 1(1), 1-5. Available at: https://doi.org/10.46557/001c.13176.

Rababah, A., Al-Haddad, L., Sial, M. S., Chunmei, Z., \& Cherian, J. (2020). Analyzing the effects of COVID-19 pandemic on the financial performance of Chinese listed companies. Journal of Public Affairs, 20(4), 1-6. Available at: https://doi.org/10.1002/pa.2440.

Ramelli, S., \& Wagner, A. F. (2020). Feverish stock price reactions to covid-19. forthcoming, review of corporate finance studies. Swiss Finance Institute Research Paper No. 20-12.

Shen, H., Fu, M., Pan, H., Yu, Z., \& Chen, Y. (2020). The impact of the COVID-19 pandemic on firm performance. Emerging Markets Finance and Trade, 56(10), 2213-2230.

Song, H. J., Yeon, J., \& Lee, S. (2021). Impact of the COVID-19 pandemic: Evidence from the US restaurant industry. International Journal of Hospitality Management, 92, 102702. Available at: https://doi.org/10.1016/j.ijhm.2020.102702.

Tadawul. (2021). Market today. Ratch from: https://www.saudiexchange.sa/wps/portal/tadawul/markets/equities/market-watch/market-watch-today?locale=ar.

Tucker, H. (2020). Coronavirus bankruptcy tracker: These major companies are failing amid the shutdown. Forbes (May 3, 2020). 